\title{
Application of innovative standards of «green» construction in Tatarstan on the example of Kazan
}

Tatyana Zakirova ${ }^{1 *}$ [0000-0001-6808-6697]

${ }^{1}$ Kazan State University of Architecture and Engineering, 420043, Zelenaya st., Kazan, Russia

\begin{abstract}
The article discusses the prospects for the application of innovative technologies in the theory and practice of urban planning on the example of Kazan. Market relations in recent decades in our country have created a number of acute problems of modern urban planning - the curtailment of long-term planning, the reduction of environmental control in the city and its environs, etc. It is necessary to refer to the Healthy Cities initiative of the World Health Organization Regional Office for Europe. The first steps in this direction have already been taken in Kazan. This is a project of the new business center of the Republic of Tatarstan «Smart City Kazan» and the first «smart house» built on the territory of the Technopolis Himgrad. In Kazan, there are prerequisites for the introduction of ecourban design methods. These are vast water areas of the Volga and Kazanka rivers, the banks of which have not yet been fully developed. This is a large square in the city center, which was vacated after moving the airport outside the city limits. For Kazan, it will also be useful to replace the decorative glass false facades, often found on brick buildings after reconstruction, with vertical «solar walls» of air thermal technology.
\end{abstract}

Keywords: green architecture, green construction, energy conservation, alternative energy sources.

\section{Introduction}

The purpose of the study is to show the process of development of green construction in Tatarstan on the example of Kazan.

The study should solve the following tasks:

- to reveal and identify green construction projects in Kazan, to analyze them and specify the materials and technologies used;

- to develop recommendations for Kazan on the use of energy-saving technologies and principles of green construction;

The scientific hypothesis of the study is that as a result of green construction, Kazan will become a «smart», socially attractive, modern city that contributes to the economic growth of the entire region, with effective urban management.

\footnotetext{
${ }^{*}$ Corresponding author: env60@yandex.ru
} 
In connection with the emergence of acute environmental problems in modern urban planning in the 1970s, the popularization of the movement for a healthy lifestyle and a clean environment began. The first private homes using alternative energy sources appeared. Gradually, in the 1970s and 80s, an understanding of the importance of energy efficiency was formed at the state level and standards of «green» construction or «green» architecture were introduced. In the 1990s, the BREEAM standard was introduced in the UK [1], and in 1992-the Energy Star program [2] in the United States. In 1999, the first meeting of the World Green Building Council was organized with the participation of eight countries: Australia, the United Kingdom, Spain, Canada, the United Arab Emirates, Russia, the United States and Japan.

Green building standards, as well as the generally accepted term «green architecture», are aimed at moving from the traditional design and construction of buildings, structures and cities to a sustainable one, including safety and favorable conditions for people, limiting the negative impact on the environment, taking into account the interests of future generations. The implementation of these principles is closely related to the use of the latest achievements of science and technology.

The term «green» architecture appeared in the 1980-s and includes not only architecture with an integrated natural component, but also energy-efficient, economical, eco-friendly, ergonomic architecture. Thus, «green» architecture is created through the interaction of engineering, landscape and architectural solutions and should be considered in their totality [3-8].

Principles of development of «green» construction:

1. The principle of energy conservation. This implies design and construction in which the heat consumption, for both heating and cooling, is minimal.

2. The principle of "cooperation» with the sun. It involves the use of solar energy as the main source of light and heat.

3. The principle of reducing the volume of new construction. The less new buildings are erected and the more old buildings, or at least the materials of old buildings, are used to build new ones, the better, as this reduces environmental pollution.

4. The principle of respect for the average person. The building does not exist to sell it. It is a place where people live, study, work. For all its spaciousness, the building should be focused on each visitor individually.

5. The principle of respect for the place. An architectural object should not be opposed to its environment. It should fit harmoniously into it. Special attention should be paid to the setting of the building in the natural environment - the architecture should not be hostile to the living world, as it is created for humans.

6. The principle of integrity. This means that all of the above principles should work together.

These principles are implemented through the introduction of a natural component in the structure of the building, energy-saving measures, as well as the compositional solution of the building in plan and volume.

\section{Materials and methods}

In his work, the author used the following research methods:

- method of analyzing the development of green construction in Kazan in accordance with the development of green construction in Russia and abroad;

- method of field studies of architectural objects and their photo fixation;

- method of studying and analyzing architectural drawings, electronic resources and literary sources;

- method of interviewing project participants. 
In this study, the author referred to the following sources:

- project materials of project organizations;

- Laws No. 111730-5-FZ No. «On Energy Saving and Energy Efficiency Improvement» and No. 384-FZ «Technical Regulations on the Safety of Buildings and Structures»;

- GOST standards and relevant national standards - Preliminary National Standard of the Russian Federation «Green» standards;

- literary sources;

- electronic resources.

In connection with the emergence of acute environmental problems in modern urban planning in the 1970s, the popularization of the movement for a healthy lifestyle and clean environment began, the first private homes using alternative energy sources appeared. Gradually, in the 1970s and 80s, an understanding of the importance of energy efficiency was formed at the state level and standards for «green» or eco-friendly construction were introduced. In the 1990s, the BREEAM (BRE Environmental Assessment Method) standard was introduced in the UK. As part of BREEAM, BRE Global supports the Sustainable Development Board, which represents the shareholders of the largest representatives of the construction industry.

BRE Global trains independent licensed BREEAM appraisers worldwide, controlled by UKAS in accordance with the ISO9001 quality system.

The BREEAM rating system is popular not only in the UK. Beyond its borders, more than 110,000 buildings have been certified to date, and about half a million buildings have yet to go through this process.

Exceeding the requirements of the legislation, apparently, was the main reason for the popularity of the BREEAM standard in the construction market.

Developers and designers are interested in improving the operational characteristics of buildings caused by the BREEAM system.

Investors and urban planning authorities are interested in reducing time and financial costs. Real estate agencies provide themselves with additional advertising. The customer, tenant or potential buyer is confident in the high quality of the final product.

Another feature of the assessment system is the method of awarding points in several sections related to various aspects of life safety, environmental impact and comfort.

The points are multiplied by weighting factors that reflect the relevance of the aspect in the building site, then summed up and translated into the resulting score.

This technique allows you to adapt the BREEAM system to different regions without losing efficiency.

Here are some of these sections:

- energy;

- water;

- materials;

- waste management;

- use of the land plot, etc.

The overall rating consists of awarding a rating: satisfactory, good, very good, excellent, and outstanding.

The BREEAM system is an example of a successful concept that effectively implements the protection of the environment from human activities by satisfying the interests of all market participants without using international or local law as a punitive tool.

In 1992, the Energy Star program was launched in the United States. Both then and now, it is considered that Energy Star is a single international standard for the energy efficiency of equipment or devices. At the same time, even at the beginning of the program, it was assumed that any device with such a logo uses the so-called economical mode of operation, in which, first of all, energy consumption is reduced by $20-30 \%$ compared to 
conventional models (now this figure ranges from 40-65\%). However, the program also applies to some other aspects, and not only to energy conservation. For example, since 1995, the voluntary certification of Energy Star standards has been extended to heating and lighting systems, and then a system of incentives for achievements in the field of energy conservation and the use of renewable energy sources has been introduced.

In 1999, the first meeting of the World Green Building Council was organized with the participation of eight countries: Australia, Great Britain, Spain, Canada, the United Arab Emirates, Russia, the United States and Japan.

Green building standards are aimed at moving from the traditional design and construction of buildings, structures and cities to a sustainable one, which includes safety and favorable conditions for human life, limiting the negative impact on the environment, taking into account the interests of future generations. The implementation of these principles is closely linked to the use of the latest achievements of science and technology.

In Russia, several dozen buildings have already been built according to LEED (Leadership in Energy and Environmental Design) standards - a voluntary certification system for buildings related to green construction, developed in 1998 by the American Council on Green Buildings to assess the energy efficiency and environmental friendliness of sustainable development projects [9] and BREEAM: these are commercial, residential buildings and sports facilities. Laws No. 111730-5 - FZ «On Energy Saving and Energy Efficiency Improvement» [10] and No. 384-FZ «Technical Regulations on the safety of Buildings and Structures» [11] were adopted.

Currently, Russia has developed and applies the national certification of green construction. These are GOST and the corresponding national standards.

\section{Results}

Kazan does not stand aside from eco-building and is actively involved in this process. In 2010, the first energy-efficient house in Russia was built in Kazan on the territory of the technopolis «Himgrad», 100 Vosstaniya Street (Fig. 1). «Green House» is a onestory 4-apartment building. As a wall material, glued beams made of coniferous wood with a thickness of $240 \mathrm{~mm}$ were used with basalt fiberboard insulation with a thickness of $70 \mathrm{~mm}$ and facing with a raised beam. Such walls retain heat 5-6 times better than masonry. When warming the roof, a $200 \mathrm{~mm}$ thick insulation is used, the base is made of $100 \mathrm{~mm}$ thick Styrofoam, for the floor a $50 \mathrm{~mm}$ thick insulation is used. At the entrance to the house, there is a thermal vestibule and a second door [12].

Energy-saving double-glazed windows with triple-glazing and filling with inert argon gas are installed. The supply and exhaust ventilation in the house is organized with the help of a heat exchanger, as well as with the help of a reversible heat exchanger system. The efficiency of the recuperator is $75-90 \%$. The energy «hearts» of the house are two heat pumps. For the needs of hot water supply, a heat pump with a capacity of $3.5 \mathrm{~kW}$ was used, for the heating needs - a reversible (allowing the same unit to both cool and heat) heat pump with a capacity of $11.5 \mathrm{~kW}$. Both heat pumps receive geothermal heat from five wells 50 meters deep. The pump takes heat from the ground, accumulates it and heats the water to a temperature of 60 degrees, after which the water is supplied to the heat supply system. The heat collector on the roof of the house complements this system and can raise the water temperature to 70-75 degrees.

A $2.5 \mathrm{~kW}$ solar battery with an inverter (220-volt converter) saves energy. Inside the house and for its outdoor lighting, only LED lamps are used. The light sensors are switched on and off by the motion sensors. The water supply system of the house is equipped with modern water purification systems. 


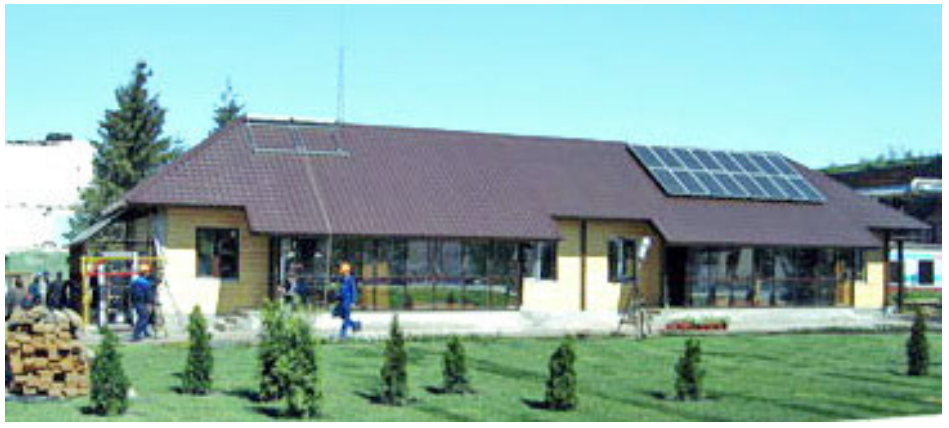

Fig 1. Energy-efficient house in the territory of the Technopolis «Himgrad» Kazan city, Vosstaniya st., 100 .

March 17, 2014 in Kazan, the start was given to the construction of a new energy-efficient house in Kazan on Khalturin Street (Fig. 2) [13]. When laying capsules with highly effective materials in the foundation of the house, the President of the Republic of Tatarstan Rustam Minnikhanov noted that, «today we are setting the standards for houses which we will build in the future. Since 2000, thanks to the introduced energy and resource saving programs, the share of energy consumption in the gross national product of Tatarstan has decreased by $50 \%$, but compared to world standards, the region consumes 2-2.5 times more energy resources».

Energy consumption in a new house is $60 \%$ less than standard values. This is achieved with a weather regulation system, ventilation with a heat recuperator, a geothermal heat pump based on soil heat exchangers, energy-efficient glazing and heat insulation of walls, LED lighting system, the use of solar panels and apartment-based adjustment of energy supply parameters. Hot water will also be heated in the house using two heating circuits. The first is a vacuum helium solar heater mounted on the roof of a technical room. Water will be heated in this way even in winter. Then, heating the water accumulated in the tanks will go at the expense of a gas wall-mounted boiler. As a result, experts believe that the cost of hot water will be $35 \%$ lower than when it is produced in a centralized way. The house also provides emergency power from solar photovoltaic panels, and LED lamps are used to illuminate the yard. There will also be LEDs at the entrance, but with light and movement sensors.

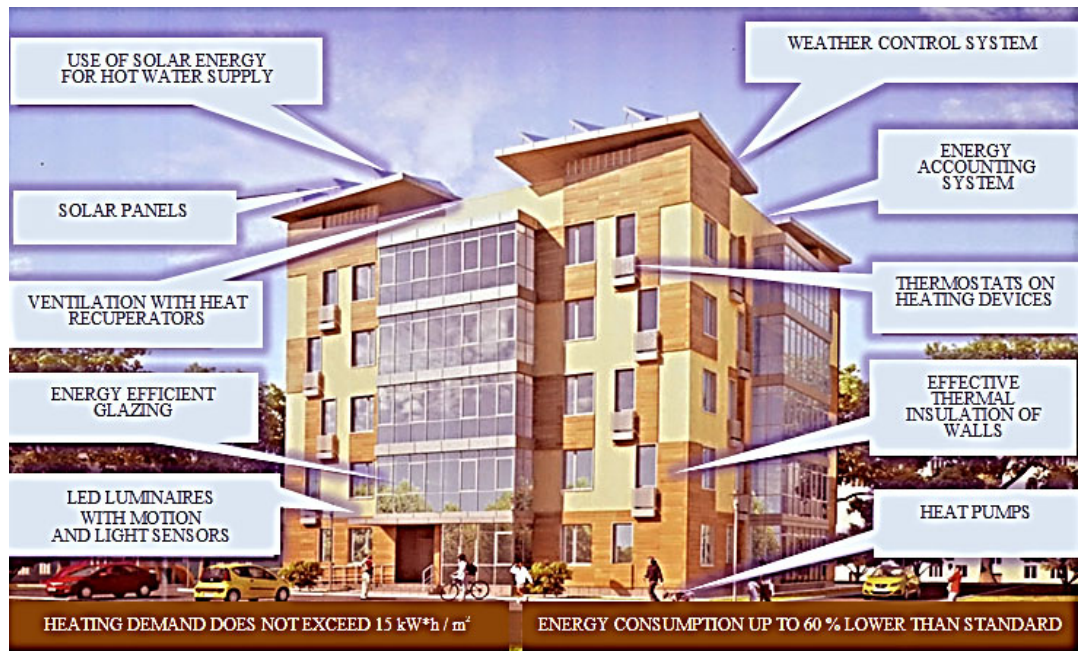

Fig. 2. The project of a residential building on Khalturin st., 2, Kazan. 
Another interesting project implemented in the Republic of Tatarstan is SMART City Kazan [14]. The implementation project of SMART City Kazan arose in 2009 from the idea of building the Kazan International Center for Exhibitions and Conferences. In 2011, the idea grew into the concept of creating a new urban space in which international business, services and the latest technologies would be developed.

SMART City Kazan is the new business center of the Republic of Tatarstan, which is located on an area of 650 hectares, in the Laishevsky district of the Republic of Tatarstan, $15 \mathrm{~km}$ from the center of Kazan, near the Kazan International Airport and will be connected to the center by the Aero express intermodal transport line, and also the P239 highway and the access road to the village of Stolbische. SMART City Kazan will receive modern infrastructure at the international level, which includes four zones: 1 - public and business center, 2 - public and educational zone, 3 park zone, 4 economic zone. The users of the new business center will be export insurance and financial companies, business service outsourcing centers, scientific and research centers and government organizations, and the International Exhibition and Conference Center [15].

The main developer of the master plan is AJM Planning \& Urban Design Group, the largest developer of general plans for large infrastructure projects in Malaysia. The main architect of the project «Smart City Kazan» Norlisa Hashim. Kazan design organization «Tatinvestgrazhdanproekt» acts as a technical partner for the general plan. The project involves drawing on Siemens' experience in implementing similar projects in the development of technical support for infrastructure and energy-saving technologies in smart cities. One of the demonstration projects of Siemens is the city of Masdar City (Abu Dhabi, UAE). Large Russian and international financial institutions will work with Tatarstan as financial consultants regarding the creation and management of the project.

On July 5, 2012, during the meeting of the President of the Republic of Tatarstan, Rustam Minnikhanov, with representatives of the Malaysian consortium (AMANAH Capital Group, Straits Consulting Engineers) and Siemens, the first concept of the «Smart City of Kazan» project was presented [16]. The AJM Planning and Urban Design Group attracted students of the Kazan State University of Architecture and Engineering to finalize the concept of the master plan of the SMART City Kazan project.

The population of Smart City Kazan in accordance with the project concept will be about 60 thousand people, and jobs - 39 thousand. It is supposed to place offices of large international and Tatarstan companies here [17].

On August 14, 2012, the Corporation for Development of the Republic of Tatarstan was established. The objectives of the new organization were to interact with external investors to create the necessary infrastructure and conditions for the implementation of investment projects in real estate. The Development Corporation was created on the initiative of the Investment Development Agency of the Republic of Tatarstan.

On September 24, 2012, in Singapore, the «Development Corporation of the Republic of Tatarstan» and the Malaysian consortium signed a contract to carry out design work on the development of the master plan for the «Smart City Kazan» project [18]. This was held as part of the VII Russian-Singapore Business Forum. The President of the Republic of Tatarstan Rustam Minnikhanov praised the work done by the consortium and emphasized that SMART City Kazan is a unique project as a whole for Russia and should be a priority for Tatarstan. The best achievements of world practice should be used in the work on the Project. 


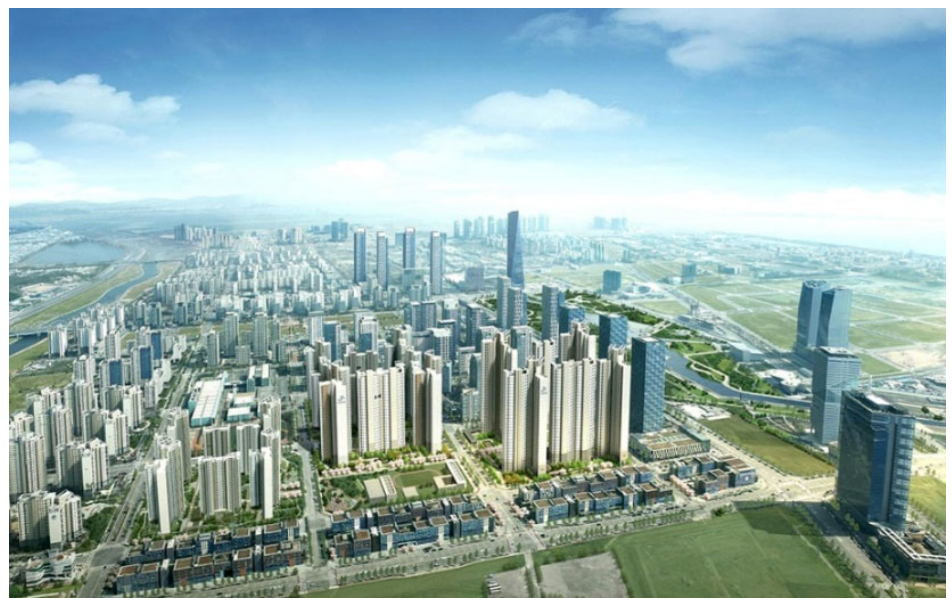

Fig. 3. Project (perspective) «SMART City Kazan».

The official start of the «SMART City Kazan» project took place on April 30, 2013 as part of the III annual AIM investment forum in Dubai, the ceremony was attended by the President of the Republic of Tatarstan Rustam Minnikhanov and the UAE Vice President, Prime Minister Sheikh Mohammed bin Rashed Al Maktoum [19]. They noted that companies from the UAE could become potential investors of the SMART City Kazan project, at the same time a Memorandum of Understanding was signed between the Development Corporation of the Republic of Tatarstan and Cisco in the field of developing an intelligent master plan for the SMART City Kazan project. In addition, agreements on investment of the project for 400 billion rubles were signed between Sberbank of the Russian Federation and the Agency for Investment Development of the Republic of Tatarstan. The American company Kronos Energy Solutions, engaged in green technologies, will participate in the creation of the innovative transport system SMART City Kazan. This company discussed the prospects of launching electric vehicles in Kazan in test mode.

On September 10, 2013, the Smart City Kazan project won the Russian stage of the FIABCI Prix d'Excellence global competition. It is one of the most prestigious global real estate competitions, which is a tool to identify the best international experience and attract the interest of international investors in local markets and their successful operators (Fig. 3). Winning the FIABCI Prix d'Excellence competition provides access to an international audience to promote their projects and companies through the FIABCI network, whose branches work in more than 60 countries and bring together specialists from more than 120 national professional associations of various specialists operating in the real estate market: developers, realtors, lawyers, appraisers, architects.

The project, which won the FIABCI Prix d'Excellence competition, embodies excellence in all the real estate sectors involved in its creation and offers humanity the best option to meet its needs. This option takes into account environmental qualities, encourages the functionality of aesthetics, the size of the project, the use of «smart» technologies.

On October 2, 2013, the construction of the International Investment Technopolis SMART City Kazan was launched within the framework of the V International Economic Summit of Russia and the Organization of Islamic Cooperation (OIC) countries (KazanSummit 2013). Four foundation stones were laid at the base of the future city, which symbolize the main zones of the International Investment Technopolis (MIT) SMART City Kazan: a scientific and educational zone, a social and business center, a special economic zone, a park zone. These zones are defined as the main economic growth points of the republic and are implemented on the site of the investment Technopolis. At the opening 
ceremony, the President of the Republic of Tatarstan emphasized that a master plan, city planning had already been made, negotiations with investors were held. Investment agreements on the implementation of SMART City Kazan have been signed. The total amount of attracted investments is about 1 billion US dollars.

The Singapore Company Radiance Hospitality Group implements three projects at the technopolis site - the University of Management and Hospitality, the hotel and office center and the apart-hotel. A consortium of investment companies from the Middle East, the Tatarstan Gulf Investment Company (TGIC), is an investor in the Kazan Expo International Center for Exhibitions and Conferences, as well as an interregional shopping center and business park. The international oil and gas services company TGT Oil and Gas Services is investing US \$11 million in the establishment of its own engineering center on the territory of SMART City Kazan and is moving its headquarters in Dubai to SMART City Kazan.

As part of the ceremony, the operator of the SMART City Kazan project was awarded a certificate from the Green Building Council (RuGBC) [13]. The certification confirms that the Development Corporation of the Republic of Tatarstan is a member of the Non-Profit Partnership for Assistance in the Creation and Implementation of Environmental Construction Norms and Rules, and uses the principles and ideas of green construction in the implementation of the SMART City Kazan project. SMART City Kazan will become an «experimental» site for green construction. Buildings will be built on the territory of the city using advanced energy-efficient solutions, mainly from renewable materials that consume a minimum of energy. The experimental status of the SMART City Kazan technopolis as an experimental site for the implementation of green standards in construction is enshrined in the orders of the Cabinet of Ministers of the Republic of Tatarstan.

\section{Discussion}

In Kazan, there are good prerequisites for the introduction of eco-city design methods: these are vast water areas of the Volga and Kazan rivers, the banks of which are not fully developed, which makes it possible to increase green spaces and reduce the amount of asphalt concrete [20]. These are large areas in the center, which were vacated after the removal of the airport and industrial zones outside the city. All this makes it possible to create high-tech, multi-storey agricultural complexes - vertical farms - in the vacated territories. These are high-rise automated greenhouses, in which the plantings will be located on different tiers of the building. Such farms will be located in an urban environment, which will significantly reduce not only transport costs, but also ensure the freshness and quality of products.

Vertical farms themselves create all the necessary conditions not only for growing crops or plants, but also for animal husbandry. In addition, vertical farms will be able to process carbon dioxide, purify process water, generate electricity from biofuels, and much more [21-26]. Vertical farms turn cities into centers for growing agricultural products, allowing the use of urban conditions that were previously unsuitable for agricultural needs. The characteristic features of the use of vertical trusses are:

- use of solar and wind energy, which ensures energy independence;

- use of autonomous systems for collecting and cleaning water, processing carbon dioxide $\left(\mathrm{CO}_{2}\right)$ and waste, using biomass energy;

- flexible construction of buildings and the possibility of installing additional modules;

- The possibility of harvesting all year round, the products are environmentally friendly (without herbicides, pesticides or fertilizers). Cases of crop failure due to unfavorable weather conditions, droughts are excluded; 
- eliminates the use of agricultural machinery, transportation costs and thus the release of harmful substances into the atmosphere;

- creates new jobs in the city.

For Kazan, it will also be useful to replace the glass decorative false facades, which have recently been used in the reconstruction of brick public buildings, with «solar walls» of the Solar Wall system type [27-28].

In addition, of course, it is necessary to actively develop the experience of the first «smart» residential building built in Kazan in the construction of the city. All this will reduce the impact of waste and prevent environmental pollution, create an energy-efficient, economical, eco-friendly, ergonomic environment through the interaction of engineering, landscape and architectural solutions [23, 29].

In the works of some authors, the constructive problems of green architecture are highlighted, in particular, the use of landscaping as a way to improve the quality characteristics of the human habitat. It is noted that due to the lack of comprehensive standards and recommendations for the design, construction and operation of «green» facilities, the development of proposals is carried out mainly on an intuitive level. Thus, the development of design and working documentation in some cases is accompanied by violations of both the operational properties of structures and their strength qualities [30].

To implement green construction, it is necessary to develop a «green» economy. Currently, the «green» economy can be designated as a new vector of sustainable development of both the country as whole and individual sectors of the economy; its key tools are recognized as innovative «green» technologies-the basis of which is innovative logistics, energy conservation, resource conservation, eco-development.

The focus of the economy on development negatively affects the preservation of the natural environment; the very basis of market relations forms an antagonism between the economy and the environment: from an economic point of view, it is not effective to apply environmental protection technologies, to finance environmental protection measures. Trends in demand can change the situation - for example, an increase in consumer interest in eco-goods or objects built using eco-technologies. Alternatively, the state, which, in contrast to the requirements of the market, will stand up to protect the interests of the population. Then fundamental scientific research, experimental design and construction of innovative buildings become important, where eco-technologies and technical solutions should be developed, as well as personnel for design, installation and maintenance should be trained and trained.

It is necessary to use financial instruments to attract investment in the «green» economy sectors; to provide state subsidies for the implementation of these projects; to develop the «green» economy sectors using public-private partnership forms; to promote cooperation with international financial organizations that finance energy efficiency programs. Organizational and management tools within the framework of market development strategies include:

- creation of the Council for the Development of the «green» economy, a clear division of functions and powers;

- coordination of activities and interagency cooperation;

- legal support;

- development and adoption of the State Concept for the development of a «green» economy [31]. 


\section{Conclusions}

In conclusion, it can be noted that because of green construction, Kazan will become a «smart», socially attractive, modern city, contributing to the economic growth of the entire region, with effective urban management. All this will contribute to the qualitative growth of social standards of living standards of the population of Kazan and at the same time will reduce the share of energy consumption in the gross national product and improve the environmental situation in the city.

\section{References}

1. BREEAM standard, URL: www.breeam.com/discover/technical-standards (last accessed: 25/03/2021)

2. ENERGY STAR standards, URL: www.energystar.gov/buildings/facility-owners-andmanagers/existing-buildings/earn-recognition/energy-star-certification (last accessed: 25/03/2021)

3. Valentina Pica, Traditional Earth Architecture in the Euro-Mediterranean Region. From Conservation to Knowledge for Sustainable Use, in Proceedings of 5th INTBAU International Annual Event (2016) New Science, New Architecture... New Urban Agenda?

4. Deependra Prashad, Urban Sustainability in Practice: Priorities in India, Lecture Notes in Civil Engineering book series 320 July 2017

5. Beatrice Marucci, Carta Di Norcia 2003: Present Situation and Prospects, Lecture Notes in Civil Engineering book series, 3 (2017) DOI: 10.1007/978-3-319-57937-5_149

6. Richard Neutra: And The Search for Modern Architecture (Thomas S. Hines, 2018)

7. Cecilia Bolognesi, Representation of Enjoyment in Ecomuseums. Analysis for Creative Placemaking in Proceedings of 5th INTBAU International Annual Event New Science, New Architecture... New Urban Agenda? (2018) DOI: 10.1007/978-3-319-57937-5_82

8. Valentina Adduci, The Environmental Sustainability of the Manor Farm System, in Proceedings of 5th INTBAU International Annual Event New Science, New Architecture... New Urban Agenda? (2018) DOI: 10.1007/978-3-319-57937-5_124

9. LEED standards URL: www.britannica.com/technology/LEED-standards (last accessed: 25/03/2021)

10. Federal Law No. 111730-5 on November 11, 2009 «On Energy Saving and Improving Energy Efficiency», URL: www.energosovet.ru/fzakon.html (last accessed: 25/03/2021)

11. Federal Law of the Russian Federation dated December 30, 2009 No. 384-FZ «Technical Regulations on the Safety of Buildings and Structures», URL: www.rg.ru/2009/12/31/tehreg-zdaniya-dok.html (last accessed: 25/03/2021)

12. The first energy-efficient house in Russia. Green House energoneftegazhim.ru/node/11 (last accessed: 25/03/2021)

13. New energy-efficient house in Kazan on Khalturin Street, URL: old.kgasu.ru/news/official/7084/ (last accessed: 25/03/2021)

14. Implementation project «SMART City Kazan», URL: kazan.aif.ru/politic/1435153 (last accessed: 25/03/2021)

15. AJM Planning \& Urban Design Group, URL: www.intelvision.ru/projects/smart-city-kazan (last accessed: 25/03/2021)

16. The first concept of the project «SMART City Kazan», URL: tida.tatarstan.ru/rus/index.htm/news/194585.html (last accessed: 25/03/2021)

17. Development Corporation of the Republic of Tatarstan, URL: tatcenter.ru/news/v-rtsozdana-korporatsiya-razvitiya-respubliki-tatarstan/ (last accessed: 25/03/2021) 
18. The official start of the project «Smart City Kazan»., URL: kazan.bezformata.com/listnews/start-proekta-smart-siti/11275359/ (last accessed: 25/03/2021)

19. Certificate from the Green Building Council (RuGBC) , URL: tida.tatarstan.ru/rus/index.htm/news/230604. html (last accessed: 25/03/2021)

20. T. R. Zakirova, Architecture of the Soviet Tatarstan. Problems of formation and development of public buildings (on the example of Kazan) (Abstract and dis. cand. Architecture, MARCHI, Moscow, Russia, 218, 1988)

21. N. Foster, Architecture and Sustainability, URL: http: // www. Fosterandpartners.com (last accessed: 25/03/2021)

22. Eamonn Canniffe, Regeneration and Resistance: Exclusive Manchester, Lecture Notes in Civil Engineering book series, 3 (2017) DOI: 10.1007/978-3-319-57937-5_155

23. Maria Mazzola, Proposal for the Urban Regeneration of the Suburban District Zen in Palermo, Italy, Lecture Notes in Civil Engineering book series, 3 (2017) DOI: $10.1007 / 978-3-319-57937-5161$

24. Ubaldo Occhinegro, Utopia. The Design of the Ideal City, Lecture Notes in Civil Engineering book series, 3 (2017) DOI: 10.1007/978-3-319-57937-5_139

25. Eric M. Nay, Sociologically Reframing Le Corbusier: Settler Colonialism, Modern Architecture and UNESCO, Lecture Notes in Civil Engineering book series, 3 (2017) DOI: $10.1007 / 978-3-319-57937-5 \_140$

26. Jodidio Philip, Architecture in Emirates (TASCHEN, 2017)

27. Jodidio Philip, Architecture in the USA (TASCHEN, 2017)

28. Solar Air Thermal Technology Solar Wall, URL: www.facepla.net/the-news/energy-newsmnu/957-solarwall.html (last accessed: 25/03/2021)

29. Richard Neutra: And The Search for Modern Architecture (Thomas S. Hines, 2017)

30. E. A. Dorozhkina, Constructive problems of «green» architecture, Urban Studies, 2017-4

31. A. E. Medovy, V. V. Medovy, Tools of "green» economy in strategies of development of the real estate market of Russia, Bulletin of the Expert Council, 2 (9), 2017 